\title{
The Navy's Numerical Hurricane and Typhoon Forecast Scheme: Application to 1967 Atlantic Storm Data ${ }^{1}$
}

\author{
ROBERT J. RENARD ${ }^{2}$ \\ Dept. of Meleorology, Naval Postgraduate School, Monterey, Calif. \\ aNd William H. Levings, III \\ Naval Academy, Annapolis, Md.
}

(Manuscript received 24 March 1969, in revised form 22 July 1969)

\begin{abstract}
Renard recently reported (Monthly Weather Reviers, July 1968) on the development of a numerical scheme for predicting the motion of tropical storms for periods up to three days. An extension of the forecast scheme, as presented here, may be described as a two-step process. First, numerical geostrophic steering of the cyclone center is accomplished using Fleet Numerical Weather Central's analyses and prognoses of smoothed isobaric height fields, called SR fields. Next, a statistical correction for vector bias in the numerical steering computation is used selectively in an attempt to enhance the accuracy of the forecast track of the storm. The bias modification is dependent solely on the peculiarities of recent history 12-and 24-hr forecasts in relation to the storm's actual trajectory. Forecasts for intervals up to $72 \mathrm{hr}$, generated from 1967 Atlantic operational storm positions, are compared to results from the previous experimental forecasts for 1965 using best-track positions of Atlantic storms.

Results indicate that the numerical scheme shows skill in relation to the official forecast accuracy for both 1965 and 1967, as documented by Fleet Weather Facility, Jacksonville, Fla. In 1967, the average relative improvement over official forecasts, using $700-\mathrm{mb}$ prognostic SR fields for steering, ranges from $52 \%$ for 12 -hr forecasts ( 90 cases) to $9 \%$ for the 48 -hr estimates (129 cases).

The paper includes a discussion of various forecast modes and selective modification schemes as well as stratification of error statistics by geographical area, storm track and stage.
\end{abstract}

\section{Introduction}

One of the authors (Renard, 1968) recently reported on the development and application of a numerical scheme to forecast the motion of tropical storm centers ${ }^{3}$ in the North Atlantic and Pacific Ocean areas. Geraldson (1968) presented a preliminary evaluation of the technique for the 1967 storm season in the west Pacific area. The subject forecast scheme, as extended and applied here, has two constituent parts. First, the storm center is geostrophically steered with winds derived from the smoothed isobaric height analyses and/or prognoses produced operationally by the Fleet Numerical Weather Central, Monterey, Calif. (FNWC) ${ }^{4}$. Next, the geostrophic steering vector is selectively modified in direc-

\footnotetext{
${ }^{1}$ Presented, in part, at the 49th Annual Meeting of the American Meteorological Society, 20 January 1969, New York City.

${ }_{2}^{2}$ Research financially supported by the Navy Weather Research Facility, Norfolk, Va.

${ }^{3}$ In this and in following sections, the term tropical storm or storm includes all stages of named tropical cyclones, unless specified otherwise.

${ }^{4}$ Although Fleet Numerical Weather Central was designated Fleet Numerical Weather Facility prior to June 1968, the former will be used throughout to designate this unit of the Naval Weather Service.
}

tion and magnitude as a function of the recent history behavior of this vector in relation to the storm's actual trajectory.

Regarding the first step, Figs. 1 and 2 illustrate operational FNWC analyses pertinent to storm forecasts generated at and after 1200 GMT 16 September 1967. Fig. 1 depicts the sea-level pressure analysis which is closely related in pattern to the $1000-\mathrm{mb}$ height field. Three hurricanes, Beulah (B), Chloe (C) and Doria (D), existed in the Atlantic area at this time. Upon application of FNWC's unique pattern separation program (Hughes, 1967) to the 1200 GMT 16 September 1967 $1000-\mathrm{mb}$ contour analysis, a smoothed height field, called SR 1000, is produced (Fig. 2). The chart resembles a space-mean height field depicting longwave features. That the hurricane circulations (i.e., perturbations) are removed by the smoothing program may be noted from a comparison of Figs. 1 and 2. The relation of the SR field to the storm trajectory is evident from the best-track positions of storms B, C and D at 12-hr intervals (Fig. 2).

As indicated in the first paragraph, the numerical geostrophic steering forecast (hereafter called the SR forecast or SR steer) may be selectively modified to 


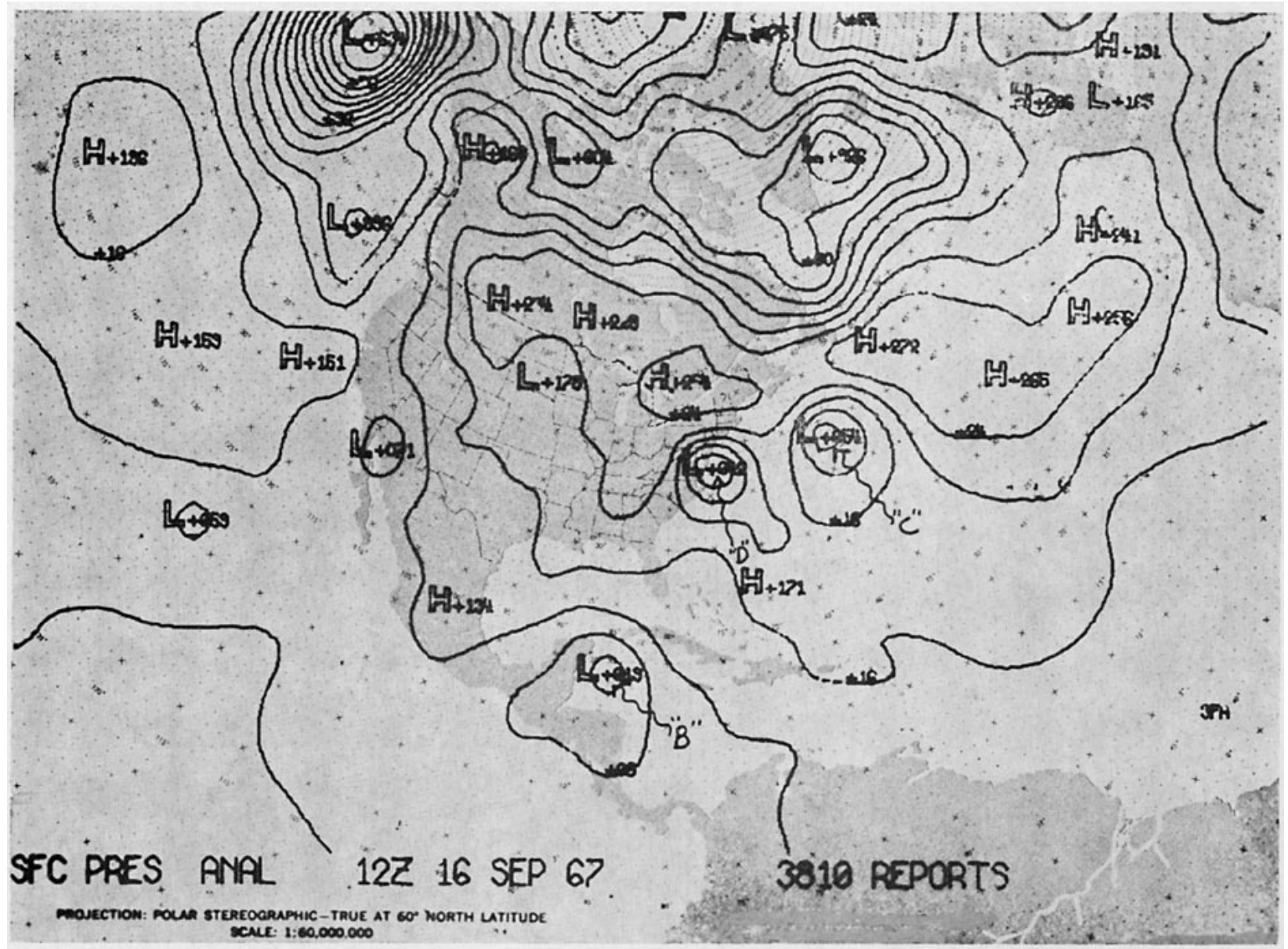

FIG. 1. Portion of the FNWC Northern Hemisphere sea-level pressure analysis for 1200 GMT 16 September 1967. B, C and D refer to hurricanes Beulah, Chloe and Doria, respectively. Isobars are at 4-mb intervals with isoline (center) labels in tens and units (tens, units and tenths) with thousandths and hundredths figures omitted.

enhance its accuracy. A schematic example of the procedure, as applied to a 36 -hr storm forecast, is shown in Fig. 3. Suppose that the current position of a tropical storm center is $T_{0}$. Twenty-four hours before time " 0 ", the position was $T_{-24}$. At that time a $24-\mathrm{hr}$ forecast of storm motion, using only the SR steer, located the center at $F_{0}$. Thus, at time " 0 " the vector error of forecast position $F_{0}$ is known; $\mathbf{E}_{24}$ represents this vector. A 36-hr SR forecast, generated at time " 0 ", locates the storm at $F_{36}$. Considering $\mathbf{E}_{24}$ as a bias in the recent-history SR forecast, it is vectorially added to the 36-hr forecast position, $F_{36}$, in the appropriate multiple, which in this case is 1.5 (i.e., $1.5 \times \mathrm{E}_{24}$ ). The result is the modified $36-\mathrm{hr}$ forecast position $F_{36}{ }^{24}$, where the superscript denotes the error field from which the correction for bias is obtained; $T_{36}$ represents the true position of the storm at time " 0 plus 36 " hr. In general, the error $\mathbf{E}_{x x}$ is applied as a correction in the multiple $y y / x x$, where $x x$ is the interval of the forecast from which the bias correction is derived and $y y$ the interval of the forecast initiated at time " 0 ".

The numerical scheme, both steps of which have been outlined above, was applied first to Atlantic tropical- storm data for 1965 and, subsequently, to 1967 . The former is summarized by Renard (1968); the latter is reported on here along with a relative comparison of the two years of application.

\section{Comparison of the 1965 and 1967 SR forecast models}

Before presenting and interpreting forecast results from the 1967 season and comparing same to the 1965 tests, it is necessary to specify the nature of the numerical geostrophic steering vector as it was used in each of the two years.

a. SR forecasts: 1965 data: 1) The data were processed by a research-oriented SR steering program written by personnel of the Department of Meteorology, Naval Postgraduate School, Monterey, Calif. (PGS). 2) The geostrophic steering computations were made in 1-hr time steps up to $72 \mathrm{hr}$. 3) The steering wind represents an average geostrophic SR wind derived from computations at four points surrounding the storm center. Each of the four points is approximately $275 \mathrm{~km}$ from the storm center. 4) Forecasts were made from 0600 and 


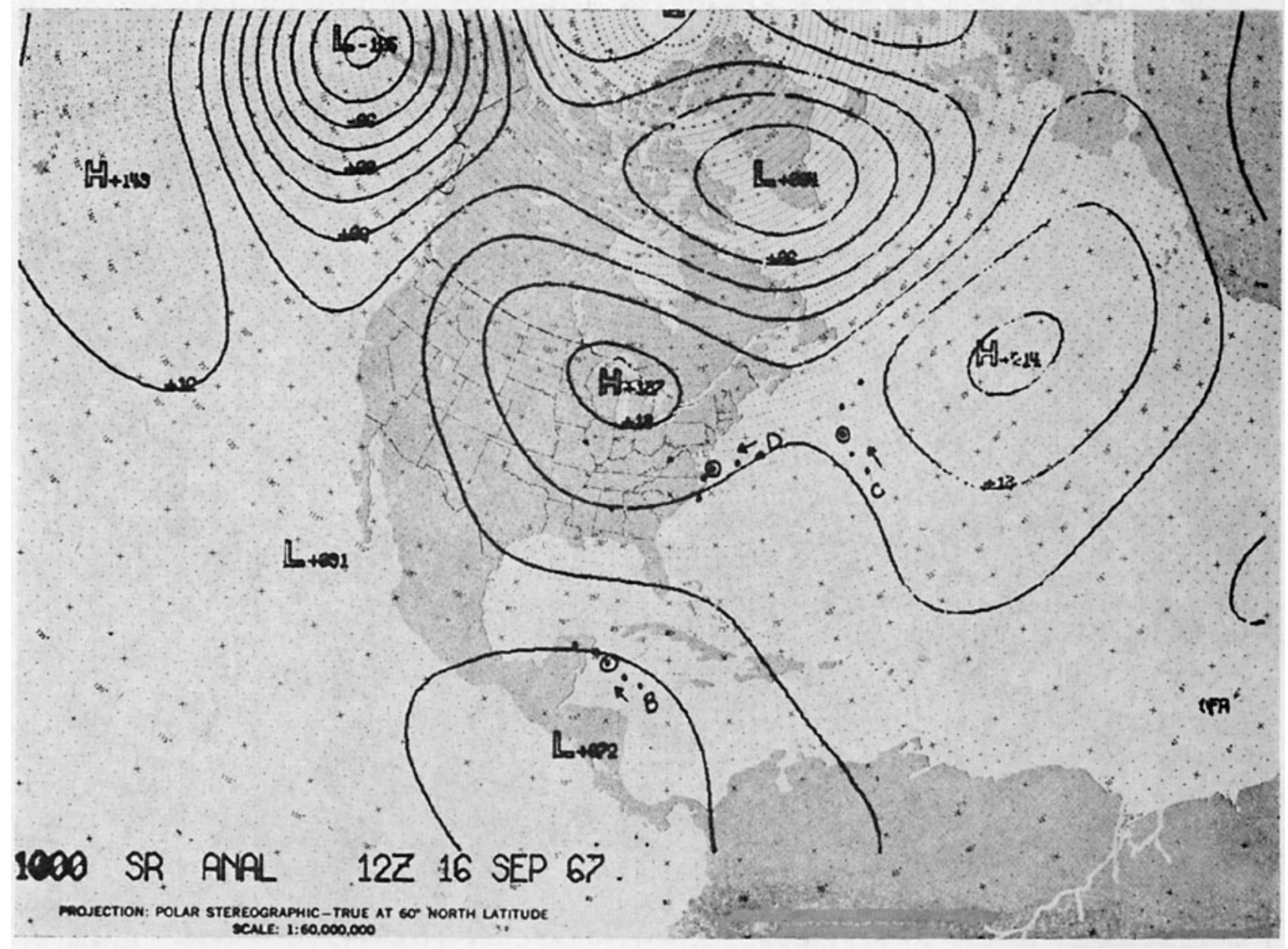

FIg. 2. Portion of FNWC's Northern Hemisphere 1000-mb SR analysis for 1200 GMT 16 September 1967. Contours are at a 30-m interval, with isoline (center) labels in tens (units) of meters. Best track positions of $B, C$ and $D$ are indicated for 12-hr intervals from 15-17 September beginning at 1200 GMT.

1800 GMT best track positions, as documented by Fleet Weather Facility, Jacksonville, Fla. (FWF JAX) (1966). 5) The FNWC SR analysis fields at 1200 and 0000 GMT were used to compute forecast positions verifying $12,24,36,48$ and $72 \mathrm{hr}$ after 0600 and 1800 GMT, respectively. 6) SR fields for various isobaric levels and layers between 1000 and $100 \mathrm{mb}$ were tested for relative accuracy in forecasting the storm centers.

b. SR forecasts: 1967 data: 1) 1967 data were processed by an operationally oriented program written by personnel at FNWC, and symbolized hereafter as HATRACK (the Hurricane and Typhoon Tracking Program). 2) HATRACK geostrophic steering computations were made in 3-hr time steps up to a maximum of $72 \mathrm{hr}$. 3) The steering wind in the HATRACK program represents the geostrophic SR wind at the storm center. 4) Forecasts were made from operational positions in real time by FNWC or Fleet Weather Central, Norfolk, Va., upon request from FWF JAX. Such positions are generally warning-time positions (i.e., position estimates at standard forecast times) at $0400,1000,1600$ and 2200 GMT, or fix-time positions (i.e., positions fixed by radar, weather reconnaissance, etc.) at or near $0000,0600,1200$ and 1800 GMT. 5) Both FNWC SR analyses and prognoses were employed

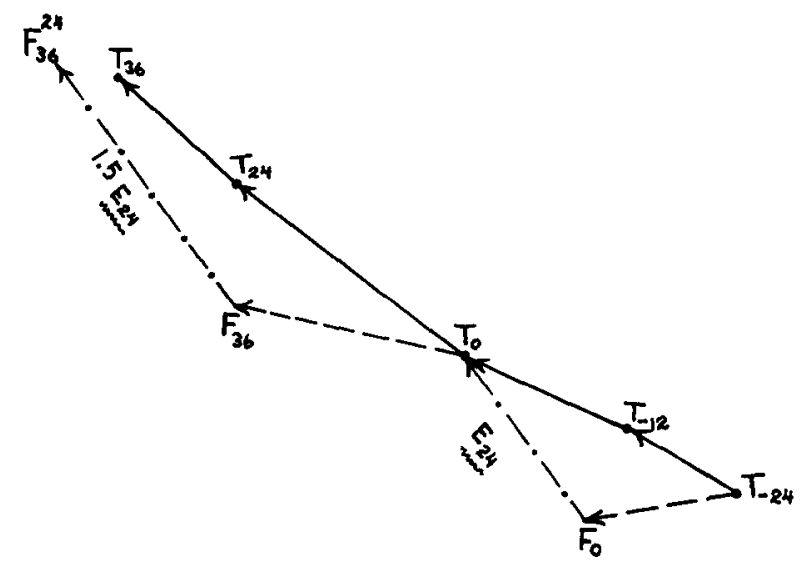

Fig. 3. Schematic example of a modified $36-\mathrm{hr}$ SR forecast initiated from position $T_{0}$ at time " 0 ". $T(F)$ is best-track (forecast) position; subscripts on $T$ and $F$ are times relative to " 0 "; superscript on $F$ refers to forecast interval from which correction for bias in $F$ is obtained. $\mathbf{E}$ is the vector forecast error, with the subscript on $\mathbf{E}$ representing the forecast interval. 


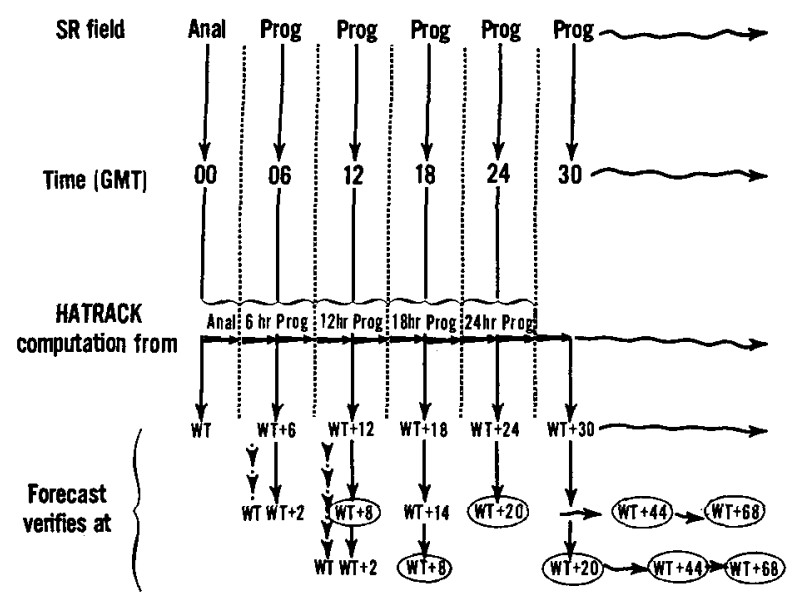

\section{WT $=$ Warning Time \\ Fcst verification time $=W T+$ Fcst interval}

FIG. 4. Schematic outline of FNWC's HATRACK steering program for both prognostic (PROG) and analysis (ANAL) modes. See text for explanation.

for the purpose of obtaining geostrophic steering computations. For one forecast mode, the most recently dated $S R$ analysis is used for computation of the geostrophic steering component; this approach will be symbolized as an ANAL-mode forecast. In another forecast mode, SR prognoses and analyses are used in the forecast of the storm trajectory; this approach will be symbolized as the PROG-mode forecast. 6) HATRACK forecasts were made regularly from SR fields at 1000,700 and $500 \mathrm{mb}$.

Fig. 4 is presented an an aid in understanding the differences between the ANAL- and PROG-mode forecasts. As an example, assume that the SR field is dated 0000 GMT and that SR prognostic fields, at 6-hr intervals out to $72 \mathrm{hr}$, are available. Further, assume a warning-time storm position at $0000 \mathrm{GMT}$. For the ANALmode storm forecast, the 0000 GMT SR field only is used to generate forecasts out to $72 \mathrm{hr}$. This same SR field is used for all subsequent warning-time positions until the 1200 GMT SR analysis becomes available. The PROG-mode forecast version utilizes the 0000GMT analysis for the initial 3-hr numerical steering step, the 6- (12-) hr SR prognosis for the two subsequent 3-hr steering steps, 0300-0600 and 0600-0900 (0900-1200 and 1200-1500) GMT, and so on, in similar fashion, to $72 \mathrm{hr}$.

As a further example, a storm position of 0400 (1000) GMT necessitates using the 6- (12-) hr SR prognosis in a 2-hr time step to 0600 (1200) GMT and a 3-hr time step to $0900(1500)$ GMT and so on. Thus, forecasts generated from the typical warning-time positions at $0400,1000,1600$ and 2200 GMT yield estimates for intervals of $2,8,14,20, \cdots, 44, \cdots, 68 \mathrm{hr}$. The standard intervals for official (OFFJAX) forecasts, as issued in real time by FWF JAX ${ }^{5}$, are 8, 20, 44 and $68 \mathrm{hr}$. Documentation of official forecast statistics, by calendar year, may be found in FWF JAX publications $(1966,1968)$.

\section{1967 HATRACK forecasts in comparison with 1965 results}

Due to several similar features of the 1965 and 1967 forecast programs, but the dissimilar nature of the tropical storm data to which they were applied (i.e., best-track positions in 1965 , operational positions in 1967), a comparative evaluation of the two years of data was undertaken. However, the focus is on the 1967 data. All available operational HATRACK forecasts from the North Atlantic for the 1967 hurricane season were obtained from FNWC and FWF JAX for use in this study. All named storms, except Ginger, are represented in the sample. Arlene, Beulah, Chloe, Doria, Fern and Heidi attained hurricane stage, while Edith and Ginger (short life in the eastern North Atlantic) did not develop beyond the storm stage.

The following serves as a common legend for Tables 1 and 2. The tables present HATRACK forecast errors for the SR level(s) of best performance. With little exception, forecasts were generated from 1000,700 and $500 \mathrm{mb}$, for each initial storm position. The isobaric level yielding the least forecast error is shown with its average error, separately for the latitude, longitude and total vector error, in nautical miles per hour of forecast interval. Statistics are presented separately for nonhomogeneous and homogeneous samples. Nonhomogeneous (homogeneous) means that the initiation time of the forecast and the forecast interval are not (are) necessarily the same for OFFJAX and HATRACK forecasts. In the nonhomogeneous set, forecast statistics are arranged into five grouped forecast intervals. The grouping simplifies the presentation of results since the 1967 HATRACK forecasts were not necessarily initiated at the same clock hour each day nor were they generally begun at hours divisible by six. The HATRACK program computes forecast positions for each $6 \mathrm{hr}$ out to $72 \mathrm{hr}$, with the first forecast computed for the nearest whole hour divisible by six. As an example, more than half of the forecasts in the 7-18 (19-30) hr group are 8 and 14 (20 and 28) hr forecasts, since forecasts were frequently generated from the standard warning-time positions at $0400,1000,1600$ and 2200 GMT. The remainder of the 7-18 (19-30) hr sample are predominantly made up of 12 and 18 (24 and 30) $\mathrm{hr}$ forecasts extending from fix-time positions at 0000 , 0600, 1200 and 1800 GMT.

The following interpretation of the $19-30 \mathrm{hr}$ grouped forecast interval in Table 1 will aid in understanding the remaining entries in this and the subse-

\footnotetext{
5 These intervals are labeled as $12,24,48$ and $72 \mathrm{hr}$ by FWX JAX (Fleet Weather Facility, 1968) since, generally, the warning-time positions are determined by extrapolation from fixes near synoptic time.
} 
TABLE 1. Average latitude, longitude and total HATRACK forecast errors $(\mathrm{kt})$ and isobaric SR level(s) of best permforance (mb) for 1967 Altantic tropical storms, with comparative results for 1965 . Sample includes PROG- and ANAL-mode forecasts. $N(O)$ represents number of HATRACK (OFFJAX) forecasts; and $E$ is interpolated error estimate for grouped interval in which OFFJAX forecasts do not exist.

\begin{tabular}{|c|c|c|c|c|c|c|c|c|c|c|c|}
\hline \multirow{3}{*}{$\begin{array}{c}\text { Forecast } \\
\text { intervals } \\
\text { (hr) }\end{array}$} & \multirow[b]{3}{*}{$\begin{array}{l}\text { Number of } \\
\text { forecasts }\end{array}$} & \multicolumn{4}{|c|}{1967} & \multirow{2}{*}{\multicolumn{2}{|c|}{ Total }} & \multirow{3}{*}{$\begin{array}{c}\text { Forecast } \\
\text { interval } \\
\text { (hr) }\end{array}$} & \multicolumn{2}{|c|}{1965} & \multirow[b]{2}{*}{ Cotal } \\
\hline & & Latit & & Long & gitude & & & & & & \\
\hline & & $\begin{array}{l}\text { HAT- } \\
\text { RACK }\end{array}$ & $\begin{array}{c}\text { OFF/ } \\
\text { HATR }\end{array}$ & $\begin{array}{l}\text { HAT- } \\
\text { RACK }\end{array}$ & $\begin{array}{l}\text { OFF/ } \\
\text { HATR }\end{array}$ & $\begin{array}{l}\text { HAT- } \\
\text { RACK }\end{array}$ & $\begin{array}{l}\text { OFF/ } \\
\text { HATR }\end{array}$ & & $\begin{array}{l}\text { Number of } \\
\text { forecasts }\end{array}$ & PGS & $\begin{array}{l}\text { OFF/ } \\
\text { HATR }\end{array}$ \\
\hline \multicolumn{12}{|c|}{ Nonhomogeneous sample } \\
\hline $7-18$ & $\begin{array}{l}N: 231 \\
O: 213\end{array}$ & $\begin{array}{l}500(700) \\
4.5(4.6)\end{array}$ & 1.07 & $\begin{array}{l}700 \\
4.4\end{array}$ & 1.43 & $\begin{array}{c}700 \\
7.1\end{array}$ & 1.01 & 12 & $\begin{array}{l}N: 93 \\
O: 137\end{array}$ & $\begin{array}{l}700 \\
7.8\end{array}$ & 0.92 \\
\hline $19-30$ & $\begin{array}{l}N: 219 \\
O: 209\end{array}$ & $\begin{array}{l}700 \\
3.9\end{array}$ & 0.92 & $\begin{array}{l}700 \\
3.9\end{array}$ & 1.21 & $\begin{array}{l}700 \\
6.2\end{array}$ & 1.05 & 24 & $\begin{array}{l}N: \quad 89 \\
O: 134\end{array}$ & $\begin{array}{l}700 \\
7.4\end{array}$ & 0.96 \\
\hline $31-42$ & $\begin{array}{l}N: 207 \\
O:-\end{array}$ & $\begin{array}{l}700 \\
3.8\end{array}$ & $0.92 E$ & $\begin{array}{l}700 \\
3.8\end{array}$ & $1.16 E$ & $\begin{array}{l}700 \\
6.1\end{array}$ & $1.02 E$ & 36 & $\begin{array}{l}N: 84 \\
O: \leq\end{array}$ & $\begin{array}{l}700 \\
7.2\end{array}$ & $0.99 E$ \\
\hline $43-54$ & $\begin{array}{l}N: 170 \\
O: 186\end{array}$ & $\begin{array}{c}1000(700) \\
3.5(3.6)\end{array}$ & 0.97 & $\begin{array}{l}700 \\
3.7\end{array}$ & 1.14 & $\begin{array}{l}700 \\
5.8\end{array}$ & 1.03 & 48 & $\begin{array}{l}N: \quad 80 \\
O: 112\end{array}$ & $\begin{array}{l}700 \\
7.2\end{array}$ & 1.00 \\
\hline & $\begin{array}{l}N: 190 \\
O: 156\end{array}$ & $\begin{array}{l}1000,700 \\
3.1\end{array}$ & & $\begin{array}{l}700 \\
3.7\end{array}$ & & $\begin{array}{l}700 \\
5.3\end{array}$ & & 72 & $\begin{array}{l}N: \quad 70 \\
O: \quad 98\end{array}$ & $\begin{array}{l}700 \\
7.1\end{array}$ & 1.06 \\
\hline \multirow[t]{2}{*}{ Average } & & & 1.00 & & 1.24 & & 1.06 & & & & \\
\hline & \multicolumn{7}{|c|}{ Homogeneous sample } & & & & \\
\hline 8 & 59 & $\begin{array}{l}500(700) \\
5.2(5.3)\end{array}$ & 0.92 & $\begin{array}{l}700 \\
5.3\end{array}$ & 1.00 & $\begin{array}{l}700 \\
8.3\end{array}$ & 0.93 & & & & \\
\hline 20 & 55 & $\begin{array}{l}700 \\
4.4\end{array}$ & 0.84 & $\begin{array}{l}700 \\
4.0\end{array}$ & 1.08 & $\begin{array}{l}700 \\
6.7\end{array}$ & 0.93 & & & & \\
\hline 44 & 42 & $\begin{array}{l}1000,700 \\
4.0\end{array}$ & 0.85 & $\begin{array}{l}700 \\
3.7\end{array}$ & 1.08 & $\begin{array}{l}700 \\
6.2\end{array}$ & 0.95 & & & & \\
\hline 68 & 20 & $\begin{array}{c}1000(700) \\
3.0(3.3)\end{array}$ & 1.00 & $\begin{array}{l}700 \\
3.5\end{array}$ & 1.35 & $\begin{array}{l}700 \\
5.2\end{array}$ & 1.18 & & & & \\
\hline Average & & & 0.90 & & 1.13 & & 1.00 & & & & \\
\hline
\end{tabular}

quent table. This group contains 219 numerical HATRACK forecasts for intervals of $19,20,21-28,29,30 \mathrm{hr}$ while 209 20-hr OFFJAX forecasts were documented. Considering the latitude and longitude component as well as the total forecast vectors, $700-\mathrm{mb}$ SR fields gave the best results in comparison with the 1000 - and 500 $\mathrm{mb}$ levels. The average latitude and longitude errors are each $3.9 \mathrm{kt}$, while the average total vector error is 6.2 $\mathrm{kt}$. In the case of the latitude component, OFFJAX errors are less than HATRACK (OFFJAX error $=0.92 \times 3.9 \mathrm{kt}$ ) but the HATRACK results excel OFFJAX in the longitudinal component as noted from an error ratio of 1.21. The total error is least for the HATRACK system with an error ratio of 1.05 .

\section{a. PROG-and ANAL-modes combined}

The following conclusions may be drawn from the nonhomogeneous 1967 sample in Table 1. The SR $700-\mathrm{mb}$ geostrophic steering winds are associated with the least error for longitude and total vector motion of the tropical storms. In the case of the latitude component, SR 500 (1000) is slightly better than SR 700 at the shorter (longer) forecast intervals. Error per hour generally decreases with increasing interval for component as well as total forecast motion. Relative to OFFJAX forecasts, the HATRACK estimates are best for the longitude component. All of the total error ratios exceed one, reflecting the influence of the longitudinal results. The error ratio, averaged over all grouped intervals, should be noted for comparison to similar data in the subsequent table.

For the 1965 nonhomogeneous data, only the totalerror statistics were computed. Also, forecast intervals were limited to $12,24,48$, and $72 \mathrm{hr}$ only. As in 1967, $700 \mathrm{mb}$ was the best level and the HATRACK forecast errors generally decreased with time. However, the error ratios are more favorable to the numerical scheme in 1967 than in 1965. This is due to the fact that, although the magnitude of forecast errors decreased for both the OFFJAX and HATRACK forecasts in 1967 as compared to 1965 , the reduction was $10 \%$ in $\mathrm{OFFJAX}$ but $17 \%$ in the numerical forecasts.

Proceeding to the homogeneous section of Table 1, error statistics are shown for a sample of OFFJAX and HATRACK forecasts from 1967. The forecast intervals are determined by those used in the OFFJAX forecasts. Conclusions on the isobaric level of best performance and time trend of forecast errors are the same as for the nonhomogeneous sample. However, HATRACK (OFFJAX) forecast errors are higher (lower) and error ratios are lower for the homogeneous sample with exceptions for OFFJAX at $8 \mathrm{hr}$ and HATRACK at $68 \mathrm{hr}$. The inconsistent behavior of this much smaller sample compared to the nonhomogeneous set is largely 
TABLE 2. Same as Table 1, except 1967 PROG-mode forecasts only.

\begin{tabular}{|c|c|c|c|c|c|c|c|}
\hline \multirow{3}{*}{$\begin{array}{c}\begin{array}{c}\text { Forecast } \\
\text { intervals } \\
\text { (hr) }\end{array} \\
7-18\end{array}$} & \multirow{3}{*}{$\begin{array}{c}\begin{array}{c}\text { Number of } \\
\text { forecasts }\end{array} \\
\\
N: 154 \\
O: 192\end{array}$} & \multicolumn{2}{|c|}{$\begin{array}{l}\text { Latitude } \\
\text { HATRACK OFF/HATR }\end{array}$} & \multicolumn{2}{|c|}{$\begin{array}{l}\text { Longitude } \\
\text { HATRACK OFF/HATR }\end{array}$} & \multicolumn{2}{|c|}{$\begin{array}{l}\text { Total } \\
\text { HATRACK OFF/HATR }\end{array}$} \\
\hline & & \multicolumn{4}{|c|}{ Nonhomogeneous sample } & & \\
\hline & & $\begin{array}{l}500(700) \\
3.6(3.7)\end{array}$ & 1.28 & $\begin{array}{l}700 \\
4.1\end{array}$ & 1.43 & $\begin{array}{l}700 \\
6.3\end{array}$ & 1.30 \\
\hline $19-30$ & $\begin{array}{l}N: 146 \\
O: 190\end{array}$ & $\begin{array}{l}700 \\
3.0\end{array}$ & 1.13 & $\begin{array}{l}700 \\
3.7\end{array}$ & 1.22 & $\begin{array}{l}700 \\
5.2\end{array}$ & 1.17 \\
\hline $31-42$ & $\begin{array}{l}N: 138 \\
0:-\end{array}$ & $\begin{array}{l}1000,700 \\
3.1\end{array}$ & $1.03 E$ & $\begin{array}{l}700 \\
3.6\end{array}$ & $1.19 E$ & $\begin{array}{l}700 \\
5.5\end{array}$ & $1.13 E$ \\
\hline $43-54$ & $\begin{array}{l}N: 129 \\
O: 171\end{array}$ & $\begin{array}{r}1000(700) \\
3.1(3.5)\end{array}$ & 1.06 & $\begin{array}{l}700 \\
3.6\end{array}$ & 1.22 & $\begin{array}{l}700 \\
5.5\end{array}$ & 1.09 \\
\hline $55-72$ & \multirow[t]{2}{*}{$\begin{array}{l}N: 152 \\
O: 145\end{array}$} & \multirow[t]{2}{*}{$\begin{array}{c}1000(700) \\
3.1(3.2)\end{array}$} & 1.06 & \multirow[t]{2}{*}{$\begin{array}{l}700 \\
3.5\end{array}$} & 1.37 & \multirow[t]{2}{*}{$\begin{array}{l}700 \\
5.2\end{array}$} & 1.21 \\
\hline Average & & & 1.11 & & 1.29 & & 1.18 \\
\hline \multicolumn{8}{|c|}{ Homogeneous sample } \\
\hline 8 & 35 & $\begin{array}{l}700 \\
3.6\end{array}$ & 1.06 & $\begin{array}{l}700 \\
5.2\end{array}$ & 1.00 & $\begin{array}{l}700 \\
7.1\end{array}$ & 0.97 \\
\hline 20 & 32 & $\begin{array}{l}1000,700 \\
2.9\end{array}$ & 1.15 & $\begin{array}{l}700 \\
3.8\end{array}$ & 1.08 & $\begin{array}{l}700 \\
5.3\end{array}$ & 1.04 \\
\hline 44 & 26 & $\begin{array}{c}1000(700) \\
2.8(3.1)\end{array}$ & 1.11 & $\begin{array}{l}700 \\
3.7\end{array}$ & 1.14 & $\begin{array}{l}700 \\
5.2\end{array}$ & 1.10 \\
\hline 68 & \multirow[t]{2}{*}{15} & \multirow[t]{2}{*}{$\begin{array}{c}1000(700) \\
2.8(3.3)\end{array}$} & 0.82 & \multirow[t]{2}{*}{$\begin{array}{r}1000(700) \\
3.3(3.5)\end{array}$} & 1.09 & \multirow[t]{2}{*}{$\frac{1000,700}{5.2}$} & 0.88 \\
\hline Average & & & 1.04 & & 1.08 & & 1.00 \\
\hline
\end{tabular}

due to the difference in the ratios of the number of forecasts for each storm to the total forecasts for all the storms in each interval. For example, consider the 7-18 and 8-hr intervals in Table 1. Arlene, a storm with a relatively large error of $8.8 \mathrm{kt}$, considering all forecasts, constitutes $12 \%$ of the nonhomogeneous sample but $17 \%$ of the homogeneous one. Heidi, a storm with a relatively small error of $3.5 \mathrm{kt}$, considering all forecasts, constitutes $12 \%$ of the nonhomogeneous sample but only $7 \%$ of the homogeneous one. All other storms appear with approximately the same ratios (to within $3 \%$ ) in both the nonhomogeneous and homogeneous sets. In view of these facts, the homogeneous sample cannot be construed as contradicting the conclusions drawn from the consideration of all HATRACK forecasts.

\section{b. PROG-mode only}

Table 2 focuses on the PROG-mode forecasts only. Omitting the ANAL-mode forecasts progressively reduces the nonhomogeneous sample by $33 \%$ at the $7-18$ $\mathrm{hr}$ interval and by $20 \%$ at the $55-72 \mathrm{hr}$ interval. The results shown in Table 2 contribute toward answering the important operational question concerning which forecast mode to apply, PROG or ANAL. On the whole the answer is clear. The PROG-mode excels the ANALmode since forecast error is reduced and error ratio increased in Table 2 compared to Table 1 while $700 \mathrm{mb}$ remains the optimum forecast level. In the case of the PROG-mode forecasts, error ratios are $>1$ for every grouped interval in the nonhomogeneous set; the same is true for most intervals in the homogeneous sample. In the latter sample, the overall average error ratios are $\geqslant 1$ for latitude and longitude components as well as the total error.

\section{1967 modified HATRACK forecasts}

From results shown in Tables 1 and 2, the SR 700 PROG-mode HATRACK forecasts appear to yield results most competitive with the OFFJAX forecast. Table 3 shows a homogeneous intercomparison of these HATRACK forecasts with their selectively modified counterparts (see Fig. 3). The so-called 12- and 24-hr modifications indicate the approximate forecast intervals from which the corrections for bias were selected. The following explains the significance of the word approximate here. In order to simulate real-time operational conditions, it was arbitrarily decided that the 12- (24-) $\mathrm{hr}$ corrections for bias be obtained from those 10,11, 12, 13, 14 and $15(22,23,24,25,26$ and 27) hr HATRACK verifications available within the period $12 \mathrm{hr}$ before initiating the forecasts. Further, the most recent forecast verification was chosen for the purpose of selectively modifying a geostrophic SR steer.

Table 3 indicates, in the case of the latitude component, that application of the 24-hr bias correction results in the least error for the latitudinal component of storm motion at every forecast interval. In the case of the longitude component, the modified forecasts equal or excel the HATRACK versions for forecast 
TABLE 3. Average HATRACK and 12- and 24-hr modified HATRACK forecast errors for 1967 Atlantic tropical storms, computed from SR $700 \mathrm{mb}$. Samples are homogeneous and for PROG-mode forecasts only.

\begin{tabular}{|c|c|c|c|c|c|c|c|c|c|c|}
\hline $\begin{array}{l}\text { Forecasts } \\
\text { intervals } \\
\text { (hr) }\end{array}$ & $\begin{array}{l}\text { Number } \\
\text { of fore- } \\
\text { casts }\end{array}$ & $\begin{array}{l}\text { HAT- } \\
\text { RACK }\end{array}$ & $\begin{array}{l}\text { Latitude } \\
\text { 12-hr } \\
\text { modified } \\
\text { HAT- } \\
\text { RACK }\end{array}$ & $\begin{array}{l}\text { 24-hr } \\
\text { modified } \\
\text { HAT- } \\
\text { RACK }\end{array}$ & $\begin{array}{l}\text { HAT- } \\
\text { RACK }\end{array}$ & $\begin{array}{l}\text { Longitude } \\
12 \text {-hr } \\
\text { modified } \\
\text { HAT- } \\
\text { RACK }\end{array}$ & $\begin{array}{c}24-\mathrm{hr} \\
\text { modified } \\
\text { HAT- } \\
\text { RACK }\end{array}$ & $\begin{array}{l}\text { HAT- } \\
\text { RACK }\end{array}$ & $\begin{array}{c}\text { Total } \\
\text { 12-hr } \\
\text { modified } \\
\text { HAT- } \\
\text { RACK }\end{array}$ & $\begin{array}{c}24-\mathrm{hr} \\
\text { modified } \\
\text { HAT- } \\
\text { RACK }\end{array}$ \\
\hline $\begin{array}{r}7-18 \\
19-30 \\
31-42 \\
43-54 \\
55-72\end{array}$ & $\begin{array}{l}75 \\
73 \\
74 \\
67 \\
79\end{array}$ & $\begin{array}{l}3.5 \\
3.1 \\
3.1 \\
3.8 \\
3.4\end{array}$ & $\begin{array}{l}3.5 \\
3.4 \\
3.3 \\
4.1 \\
3.7\end{array}$ & $\begin{array}{l}2.9 \\
2.7 \\
2.7 \\
3.5 \\
3.4\end{array}$ & $\begin{array}{l}3.9 \\
3.6 \\
3.6 \\
3.7 \\
3.8\end{array}$ & $\begin{array}{l}3.2 \\
3.6 \\
3.7 \\
4.0 \\
4.3\end{array}$ & $\begin{array}{l}3.3 \\
3.4 \\
3.7 \\
4.4 \\
4.9\end{array}$ & $\begin{array}{l}5.9 \\
5.4 \\
5.3 \\
6.0 \\
5.6\end{array}$ & $\begin{array}{l}5.3 \\
5.4 \\
5.6 \\
6.6 \\
6.5\end{array}$ & $\begin{array}{l}4.9 \\
4.7 \\
5.1 \\
6.3 \\
6.7\end{array}$ \\
\hline
\end{tabular}

intervals up to $30 \mathrm{hr}$. After $30 \mathrm{hr}$, HATRACK without modification is best. The total error statistics, reflecting both the influence of the latitude and longitude components, indicate that the 24-hr modified HATRACK is best at intervals up to $48 \mathrm{hr}$ while the HATRACK system excels for forecasts in the intervals $43-72 \mathrm{hr}$.

It is desirable to present a homogeneous sample of modified and unmodified HATRACK forecasts to include the OFFJAX forecasts. However, since the number of such cases in 1967 (maximum of 15 in the 8 -hr interval) is too small to give significance to the result, tables of such statistics are not shown here.

\section{Optimal numerical forecast scheme, 1967 vs 1965}

Table 4 compares the optimal results from 1965 and 1967 data samples, considering the total vector forecast storm motion only. SR 700 is the isobaric level which yields the least forecast error in both years. In 1965 only ANAL-mode forecasts were computed; in 1967 the PROG-mode gave better results than the ANAL-mode. In 1965, forecast statistics were stratified by individual forecast intervals whereas in 1967 interval grouping was necessary. The number of forecasts sampled increased from $3 \%$ at small to $120 \%$ at large forecast intervals from 1965 to 1967 . The optimal numerical scheme utilizes a correction for bias for forecast intervals through $36 \mathrm{hr}$ in both years, with the 24- (12-) hr bias correction best in 1967 (1965). In 1967 the SR geostrophic steering scheme, unmodified, excels in the late forecast intervals, starting with $43 \mathrm{hr}$, while the same is not true for 1965 except for 72-hr forecasts. The numerical forecast errors are more stable with time in 1967 than in 1965. Forecast accuracy in 1967 increases with time relative to 1965; after $24 \mathrm{hr}$, errors are least for 1967.

The error ratios in Table 4 show a stability trend similar to the error itself in the two years sampled. However, the 1967 error ratios are more unfavorable to the optimal numerical scheme through $42 \mathrm{hr}$ compared to 1965; the reverse is true after that time. There are several differences in the two years of storm data sampled which contribute to this relative behavior of error ratios. In 1965, the more accurate best-track data were used for initial forecast positions whereas in 1967 only real-time operational positions were utilized for this purpose. In 1967, considering only those initial storm positions used to generate HATRACK forecasts, the average distance from the operational to the best track position is $32 \mathrm{n} \mathrm{mi}$. The effect of this stormposition error on the HATRACK forecast error per hour is greatest for the smallest forecast intervals but decreases with increasing interval. However, with increasing interval another influence prevails. A PROGmode forecast utilizes a steering field dated within $3 \mathrm{hr}$ of the storm position at any point in the forecast trajectory (see Fig. 4). For the ANAL mode, the time of the steering field is earlier than the time of the storm

TABLE 4. Summary of performance of Navy's numerical tropical storm forecast scheme from nonhomogeneous 1965 and 1967 samples of total vector forecast errors using SR $700 \mathrm{mb}$. Optimal indicates scheme with best performance, symbolized as $F_{x x^{y y}}$, where $x x$ refers to interval of forecast $F$ and $y y$ refers to that forecast interval from which the bias correction is obtained.

\begin{tabular}{|c|c|c|c|c|}
\hline $\begin{array}{c}\text { Forecast } \\
\text { intervals } \\
\text { (hr) }\end{array}$ & $\begin{array}{l}\text { Optimal } \\
\text { NUM } \\
\text { scheme }\end{array}$ & $\begin{array}{l}\text { Number of } \\
\text { forecasts }\end{array}$ & 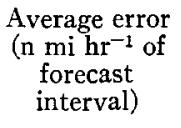 & $\begin{array}{c}\text { Error ratio } \\
\text { OFF/Opt } \\
\text { NUM }\end{array}$ \\
\hline \multicolumn{5}{|c|}{ 1965: ANAL-mode forecasts } \\
\hline 12 & $F_{\mathbf{1 2}}{ }^{12}$ & $\begin{array}{l}N: 87 \\
O: 137\end{array}$ & 3.9 & 1.83 \\
\hline 24 & $F_{24^{12}}$ & $\begin{array}{l}N: 83 \\
O: 134\end{array}$ & 4.9 & 1.46 \\
\hline 36 & $F_{36}{ }^{12}$ & $\begin{array}{l}N: \quad 78 \\
O: \quad-\end{array}$ & 5.9 & $1.23 E$ \\
\hline 48 & $F_{48}{ }^{12}$ & $\begin{array}{l}N: 75 \\
O: 112\end{array}$ & 6.8 & 1.06 \\
\hline 72 & $F_{72}$ & $\begin{array}{ll}N: & 70 \\
O: & 98\end{array}$ & 7.1 & 1.06 \\
\hline \multicolumn{5}{|c|}{ 1967: PROG-mode forecasts } \\
\hline $7-18$ & $F_{x x^{24}}$ & $\begin{array}{l}N: 90 \\
O: 192\end{array}$ & 5.4 & 1.52 \\
\hline $19-30$ & $F_{x x^{24}}$ & $\begin{array}{l}N: 85 \\
O: 190\end{array}$ & 4.9 & 1.24 \\
\hline $31-42$ & $F_{x x^{24}}$ & $\begin{array}{l}N: 83 \\
O:-\end{array}$ & $5: 2$ & $1.13 E$ \\
\hline $43-54$ & $F_{x x}$ & $\begin{array}{l}N: 129 \\
O: 171\end{array}$ & 5.5 & 1.09 \\
\hline $55-72$ & $F_{x x}$ & $\begin{array}{l}N: 152 \\
O: 145\end{array}$ & 5.2 & 1.21 \\
\hline
\end{tabular}


TABLE 5. Average HATRACK forecast errors $(\mathrm{kt}$ ) for 1967 Atlantic tropical storms as computed from SR $700 \mathrm{mb}$ and stratified by geographical area, storm track and stage of development. Sample includes both PROG- and ANAL-mode forecasts. See Fig. 5 for definitions of areas $\mathrm{A}, \mathrm{B}, \mathrm{C}$.

\begin{tabular}{|c|c|c|c|c|c|c|c|c|c|c|c|c|c|c|c|c|c|c|c|c|}
\hline & $\begin{array}{l}\text { No. of } \\
\text { fore- } \\
\text { casts }\end{array}$ & $\begin{array}{r}7-1 \\
\text { Lat. }\end{array}$ & $\begin{array}{l}18 \mathrm{hr} \\
\text { Long. }\end{array}$ & Total & $\begin{array}{l}\text { No. of } \\
\text { fore- } \\
\text { casts }\end{array}$ & $\begin{array}{l}19-3 \\
\text { Lat. }\end{array}$ & Long. & Total & $\begin{array}{l}\text { For } \\
\text { No. of } \\
\text { fore- } \\
\text { casts }\end{array}$ & $\begin{array}{l}\text { ecast } \\
31-4 \\
\text { Lat. }\end{array}$ & $\begin{array}{l}\text { interva } \\
2 \mathrm{hr}\end{array}$ & Total & $\begin{array}{l}\text { No. of } \\
\text { fore- } \\
\text { casts }\end{array}$ & $\begin{array}{l}\text { 43-5 } \\
\text { Lat. }\end{array}$ & $\begin{array}{l}54 \mathrm{hr} \\
\text { Long. }\end{array}$ & Total & $\begin{array}{l}\text { No. of } \\
\text { fore- } \\
\text { casts }\end{array}$ & $\begin{array}{l}55-7 \\
\text { Lat. }\end{array}$ & $\begin{array}{l}2 \mathrm{hr} \\
\text { Long. }\end{array}$ & Tota \\
\hline \multicolumn{21}{|c|}{ Geographical area } \\
\hline A & 119 & 5.4 & 4.8 & 8.2 & 117 & 4.6 & 4.4 & 7.2 & 112 & 4.6 & 4.1 & 7.1 & 89 & 4.0 & 4.3 & 6.5 & 95 & 3.5 & 4.7 & 6.4 \\
\hline $\mathrm{B}$ & 74 & 2.7 & 3.1 & 4.5 & 65 & 2.0 & 2.3 & 3.5 & 60 & 1.9 & 2.3 & 3.2 & 51 & 2.1 & 2.0 & 3.3 & 62 & 2.2 & 1.8 & 3.1 \\
\hline $\mathrm{C}$ & 38 & 5.7 & 5.8 & 8.8 & 37 & 5.0 & 5.2 & 7.8 & 35 & 4.5 & 5.4 & 7.8 & 30 & 5.0 & 4.9 & 8.0 & 33 & 3.6 & 4.4 & 6.3 \\
\hline \multicolumn{21}{|c|}{ Storm track } \\
\hline $\begin{array}{l}\text { Before re- } \\
\text { curvature }\end{array}$ & 159 & 3.8 & 4.2 & 6.2 & 144 & 3.1 & 3.3 & 5.1 & 131 & 3.0 & 3.0 & 4.8 & 111 & 3.3 & 2.9 & 4.9 & 123 & 2.9 & 2.7 & 4.3 \\
\hline $\begin{array}{l}\text { After re- } \\
\text { curvature }\end{array}$ & 72 & 6.4 & 4.9 & 9.1 & 75 & 5.5 & 5.1 & 8.3 & 76 & 5.2 & 5.2 & 8.3 & 59 & 4.2 & 5.2 & 7.5 & 67 & 3.5 & 5.5 & 7.2 \\
\hline \multicolumn{21}{|c|}{ Stage of development } \\
\hline Depression & 28 & 4.4 & 4.4 & 6.3 & 22 & 3.7 & 2.4 & 5.0 & 17 & 4.3 & 2.3 & 5.4 & 13 & 4.5 & 2.2 & 5.3 & 18 & 3.8 & 2.5 & 4.9 \\
\hline Storm & 56 & 5.3 & 5.0 & 8.0 & 51 & 4.5 & 4.1 & 7.0 & 48 & 4.5 & 3.9 & 6.9 & 42 & 3.2 & 4.0 & 6.1 & 46 & 2.1 & 4.3 & 5.3 \\
\hline Hurricane & 144 & 4.3 & 4.2 & 6.9 & 142 & 3.6 & 4.1 & 6.0 & 133 & 3.2 & 3.9 & 5.7 & 110 & 3.6 & 3.7 & 5.7 & 124 & 3.4 & 3.7 & 5.4 \\
\hline $\begin{array}{l}\text { Extra- } \\
\text { tropical }\end{array}$ & 3 & 6.3 & 2.0 & 6.9 & 4 & 8.7 & 3.6 & 9.6 & 9 & 7.6 & 4.4 & 9.3 & 5 & 4.5 & 4.8 & 7.1 & 2 & 1.0 & 2.3 & 2.6 \\
\hline
\end{tabular}

position in its forecast trajectory by a number of hours equal to or greater than the forecast interval. In combination, these two factors may account for the lowering of the error ratio at small intervals but its increase at later intervals in 1967 compared to 1965.

Another feature is evident in the 1967 data; namely, the inability of the correction for bias to improve upon the HATRACK forecasts for intervals $>42 \mathrm{hr}$ and the relatively small improvement in forecast error due to this correction at intervals <43 hr. In 1965 the correction for bias gave an improvement over the unmodified forecast which amounted to $50 \%$ for 12 -hr forecasts; in 1967 the improvement was only $18 \%$ in a similar forecast interval. In explanation, a part of the bias inherent in the 1965 ANAL-mode forecasts was removed in 1967 by using SR prognostic fields instead of a single SR analysis for deriving the steering winds.

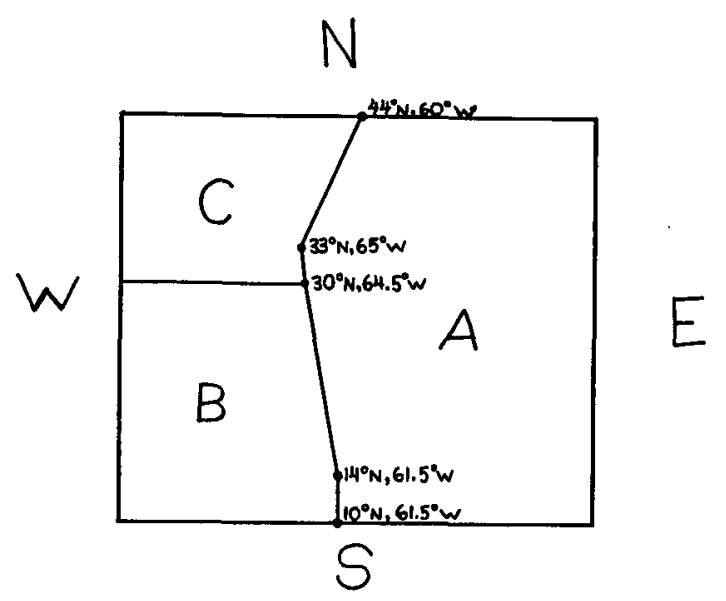

FIG. 5. Typical geographical division of the North Atlantic Ocean area $(\mathrm{A}, \mathrm{B}, \mathrm{C})$ for the purpose of stratifying tropical storm forecast statistics (Tracy, 1966).

\section{Concluding remarks}

An analysis of the behavior of the Navy's numerical hurricane forecast scheme, as applied to both 1967 and 1965 Atlantic data, indicates skill relative to the official forecast. The ready availability of such forecasts to the hurricane forecaster, in combination with its relative accuracy, suggests that the HATRACK forecast, selectively modified in accordance with Table 4 , provides a suitable objective base from which further improvement may be achieved by the experienced official forecaster.

One further table is presented to indicate the direction in which the Navy's tropical storm research is being directed. Table 5, for all 1967 HATRACK forecasts, indicates errors by geographical area, storm track and stage. Minimal forecast errors are committed in Atlantic area B (see Fig. 5) for a depression or hurricane moving on a westward path at latitudes equatorward of the $700-\mathrm{mb}$ subtropical ridge line. Thus, the next step is to stratify the forecast scheme itself by area, track, stage and other geographical and meteorological criteria in order to enhance and tailor its performance. However, another two years or more of data are needed for this purpose.

Although it is realized that a dynamic prognostic model ultimately holds the key for an all inclusive movement-development approach to the tropical storm forecast problem (Sanders, 1968), results quoted here serve to suggest use of the selectively modified HATRACK scheme in the interim period of development of such a model.

Acknowledgments. The authors thank the Navy Weather Research Facility, Norfolk, Va., for continuing financial support of the tropical storm forecast project and Fleet Numerical Weather Central, Monterey, Calif., and Fleet Weather Facility, Jacksonville, Fla., for furnishing HATRACK forecast data and valuable 
advice. Appreciation is extended to Steve Rinard and James Cerullo, Department of Meteorology, Naval Postgraduate School, Monterey, Calif., for their contributions in data handling and computations.

\section{REFERENCES}

Fleet Weather Facility, 1966: Annual tropical storm report-1965 (OpNav Rept. 3140-9). U. S. Naval Air Station, Jacksonville, Fla., $73 \mathrm{pp}$.

-_, 1968: Annual tropical storm report-1967 (OpNav Rept. $3140-9)$. U. S. Naval Air Station, Jacksonville, Fla., 98 pp.
Geraldson, E. L., 1968: A comparison of the accuracy of objective techniques for forecasting typhoon movement during 1967. Mon. Wea. Rev., 96, 649-653.

Hughes, R. E., 1967: U. S. Naval Weather Service computer products manual (NAVAIR 50-IG-522). Dept. of the Navy, Washington, D. C., $261 \mathrm{pp}$.

Renard, R. J., 1968: Forecasting the motion of tropical cyclones using a numerically derived steering current and its bias. Mon. Wea. Rev., 96, 453-469.

Sanders, F., 1968: Experiments in barotropic hurricane forecasting. J. Appl. Meteor., 7, 313-323.

Tracy, J. D., 1966: Accuracy of Atlantic tropical storm forecasts. Mon. Wea. Rev., 94, 407-418. 